\title{
ECONOMIC SUSTAINABILITY OF EARLY POTATO PRODUCTION IN THE MEDITERRANEAN AREA
}

\author{
Filippo Sgroi, Anna Maria Di Trapani, Riccardo Testa and Salvatore Tudisca \\ Department of Agricultural and Forestry Sciences, University of Palermo, Italy
}

Received 2014-07-18; Revised 2014-08-06; Accepted 2014-08-09

\begin{abstract}
The interactions between a given commercial enterprise, its territory and development, have become a key issue in recent years. Theories of economic development tell us that a territory may undergo development provided viable, economically sustainable commercial activities exist. Based on the latter postulate, the present paper analyzes the economic sustainability of farming enterprises growing early potatoes in a Mediterranean setting. In particular, the study was conducted in south-eastern Sicily, island in the centre of the Mediterranean. The results underscore their modest profitability, mainly due to a lack of entrepreneurial strategies aimed at enhancing production. This situation leads to shortcomings in terms of economic viability of the considered activities, which according to economic theory underlie an ultimate impoverishment of the territory.
\end{abstract}

Keywords: Early potato, Sustainability, Profitability

\section{INTRODUCTION}

The early potato is one that is well suited to the soil and climatic conditions of the regions of southern Italy (Sicily, Apulia, Campania and Sardinia) and Mediterranean countries (Cantore et al., 2014; Ierna and Parisi, 2014; Rykbost et al., 2003). The main feature that differentiates the early potato from the common varieties lies in the early sowing, which takes place in autumn and early winter (November-January) and may thus be harvested significantly in advance (March-May).

This allows growers to come to market as soon as mid-March with a small-sized product, whose thin skin can be easily rubbed off, a trait which is highly appreciated by consumers. Production usually fetches higher prices than common potatoes depending both on low unitary productions and also on their being harvested in advance.

The cultivation cycle of the early potato is made possible by favorable climatic conditions that persist throughout the winter season in the regions of southern Italy (Agnese et al., 2008; D'Asaro et al., 2014; D'Asaro and Grillone 2014; Grillone et al., 2009; Tudisca et al., 2013a).
In 2011 , the early potato represented an average $23.9 \%$ of the national production of potatoes in Italy, covering $29.7 \%$ of the relative surface. In particular, there was a production of 3.8 million tons, distributed across an area of 18,512 ha (Table 1).

National production of early potatoes, appears essentially concentrated in southern regions; among these, four (Sicily, Apulia, Campania and Sardinia) represent as much as $89.9 \%$ of the national investment and $90.5 \%$ of the relative production.

The foremost producer is the region of Sicily that in 2011, with 9,075 hectares and 1.9 million quintals, totaled $49.0 \%$ of the area under potato and $48.3 \%$ of the national production; then followed Campania (3,101 ha), Apulia (2,940 ha) and Sardinia (1,525 ha). As compared to 2010, Italian production of early potato in 2011 experienced a slight increase both in terms of surfaces $(+2.2 \%)$ as well as production $(+4.3 \%)$. This situation is the aggregate result of various interrelated variables, such as fluctuations in prices and production factors and entrepreneurial expectations concerning the economic performance a given product might determine on the enterprise, in light of strategies to diversify its agricultural Corresponding Author: Filippo Sgroi, Department of Agricultural and Forestry Sciences, University of Palermo, Italy 
products, just to mention a few (Tudisca et al., 2014a; 2014b). From a competitive perspective, Italian potatogrowing companies compete against countries of North Africa, where the crop finds favorable climatic and pedological conditions and most importantly, where production costs are lower (Van Der Waals et al., 2003). Italian early potatoes, in fact, are in want of competitiveness with regard to the productions of some North African Countries (such as Egypt), that arrive on the market up to a month in advance and at lower prices. Italian production must also compete with Israeli production, that boasts high standards of quality. This situation means that output producer prices of Italian potatoes quite often become scarcely remunerative for the entrepreneur, especially in years of high supply. All the above, together with declining levels of consumption of fresh potatoes in the internal market, determines a lack of competitiveness on the part of Italian companies cultivating potatoes. Another factor that limits competitiveness on behalf of Italian potato growing firms is the scarcity of foreign commercial outlets. In fact, the fraction of production commercially destined to export is targeted to Germany, almost exclusively. In this sense, eastern European countries might be interesting additional markets, considering Italy's relative proximity to, say, Poland, as compared to Spain, one of its main competitors.

Analyzing the main producing regions, however, it is interesting to note the contrasting trends characterizing Apulia and Campania between 2010 and 2011. The former, in fact, registered a marked decrease in both crop area $(-16.5 \%)$ and quantities produced $(-26.3 \%)$, due to faulty commercial organization, as well as to fragmentation of productive structures, that determine marginal levels of remuneration from the input employed in production processes. Campania, on the other hand, exhibited an appreciable increment of investments into early potato cultivation $(+26.1)$, thus boosting its production (+31.9). These increases can be attributed to an improved level of organization of production supply, thus enabling better planning of production, rewarded by more handsome remuneration of the factors of production.

In Sicily, companies growing potatoes amounted to 3,805 units (ISTAT, 2012), representing 19.2\% of all companies nationally. Early potato crops in Sicily represent much of the area under potatoes, aligning $81.6 \%$ of the regional investment to the $83.1 \%$ of the total production. The widespread distribution of the crop is due to the favourable climate of the island (Grillone et al., 2014; 2012; Tudisca et al., 2014c; 2013b), that encourages entrepreneurs to include it among their cropping systems.
Most potato cultivation takes place in the southeastern part of Sicily (Syracuse), where $69.4 \%$ of investments $(6,300 \mathrm{ha})$ are concentrated and $71.2 \%$ of quantities are produced (1.3 million q). The provinces of Caltanissetta and Ragusa follow, together accounting for $20.8 \%$ of regional land and $16.0 \%$ of the production (Table 2). In western Sicily, on the other hand, Agrigento and Trapani together comprise $5.0 \%$ of the areas under early potato and $4.5 \%$ of regional production. In these provinces, early potatoes are grown in the context of mixed cropping systems, being sown interplanted with other crops (horticulture-viticultureolive growing). Compared to 2010, Sicily recorded a decline as far as crop areas were concerned $(-1.0 \%)$, but not in early potato production $(+0.3)$. As in other regions of southern Italy, the predicament for early productions in Sicily is the fact that there are very few organized systems that aggregate supply and enhance the value of products. The present status hampers the institution of a competitive enterprise system. Indeed, in light of the fact that much of the retail consumer demand is dominated by large supermarket chains for a big share of the market, as long as the prerequisite of certainty of supply stands, micro-enterprises in Sicily and southern Italy are unlikely to win their way into this circuit.

Table 1. Area and production of early potato in Italy

\begin{tabular}{lllll}
\hline & 2010 & & 2011 & \\
& -------- & - & \\
Regions & ha & quintals & ha & quintals \\
\hline Sicily & 9,170 & $1,853,135$ & 9,075 & $1,859,030$ \\
Apulia & 2,458 & 670,589 & 3,101 & 884,857 \\
Campania & 3,523 & 640,775 & 2,940 & 472,500 \\
Sardinia & 1,523 & 261,231 & 1,525 & 265,372 \\
Others & 1,436 & 262,714 & 1,871 & 367,087 \\
Italy & 18,110 & $3,688,444$ & 18,512 & $3,848,846$ \\
\hline
\end{tabular}

Source: Our elaboration on ISTAT data

Table 2. Area and production of early potato in Sicily

\begin{tabular}{lllll}
\hline & 2010 & & 2011 & \\
& -------------- \\
Provinces & ha & quintals & ha & quintals \\
\hline Syracuse & 6,300 & $1,305,000$ & 6,300 & $1,323,000$ \\
Ragusa & 1,000 & 200,000 & 1,000 & 200,000 \\
Caltanissetta & 700 & 105,200 & 650 & 97,500 \\
Agrigento & 410 & 78,735 & 425 & 81,130 \\
Messina & 450 & 90,000 & 400 & 80,000 \\
Catania & 250 & 70,000 & 270 & 75,000 \\
Trapani & 60 & 4,200 & 30 & 2,400 \\
Sicily & 9,170 & $1,853,135$ & 9,075 & $1,859,030$ \\
\hline Source: & &
\end{tabular}

Source: Our elaboration on ISTAT data 
In this scenario, given that the entrepreneur producing potatoes operates under conditions of free market competition and thus is subject to market prices, determining the market price that allows the firm to cover its costs of production, surpassing which positive profit margins ensue, assumes particular importance in order to better orient business options.

In particular, through empirical analysis, in order to verify the economic sustainability of the early potato, it was determined the production cost and the profit of the crop.

\section{MATERIALS AND METHODS}

Besides its performance in the marketplace, the lesser or greater ability of a company to produce revenue derives from the constraints under which its activities are carried out (Sgroi et al., 2014a).

These constraints relate to the very structure of the undertaking and to the external environment. Internal constraints include those relative to production capacity (regarding both quality and quantity), financial capacity, organizational capacity and, finally, potential in economic structural terms.

The latter depends on the cost structure and business revenues, particularly with regard to the interrelationship between fixed and variable costs and revenues. Indeed, profitability is a company's ability to cover costs by achieving revenues with ensure an adequate return on the inputs wielded in economic units, while affording the proprietor commensurate proceeds (Sgroi et al., 2014b). The comparison of revenues and costs is indispensable, in both budget and balance sheet, to evaluate the effects of choices in cost-volume-profit analyses. In fact, for proper business management, one must understand which variables of the production process to act upon, or, if feasible, which products to abandon and which to start producing (Santeramo et al., 2012).

The latter aspect comprises the crucial planning horizon where the entrepreneur can choose among all technically viable solutions. In fact, in the long term the entrepreneur can modify all the factors of production.

However, after the options of the production planning stage, matters lapse back into free market conditions where at least one factor becomes fixed.

From the agronomical point of view, the choice depends on the pedological and climatic conditions and, if one wants to orient production towards herbaceous crops, the selection of a suitable crop rotation system. Once a culture has been chosen, one can act only on some factors of production, namely the variable ones.

To this end, an economic survey was conducted on a representative case study (Testa et al., 2014a; Tudisca et al., 2013c) of a company producing early potatoes in the south-eastern part of Sicily.

The case study selected appears consistent with the objectives of the study, i.e., to evaluate economic sustainability and thus profitability of the crop.

To estimate profitability of the crop, costs and revenue were determined. The total cost of production was broken down into variable and fixed costs. The former category includes the cost of cultivation procedures, fertilizers, sowing, crop treatments, cost of maintenance and repairs of capital assets throughout multiple production cycles, harvesting-crating costs, transport costs, commissions, capital interest and taxes (Prestamburgo and Saccomandi, 1995). Every debit entry was determined by adding up (if present) labour costs and those for out-of-house materials.

Fixed costs are those relative to depreciation on durable capital assets (agrarian and land), administration expenses and supervision and those for land (i.e., price for land use) (Sgroi et al., 2014c).

To determine revenues, so as to obtain a value independent of more or less favourable yearly fluctuations, an average of the preceding four years (2009-13) was considered, producing a value of 178 $\mathrm{q} / \mathrm{ha}$. These data refer to the volumes produced by the company itself, as well as to a parallel analysis carried out on local operators in the territory of the study.

The monetary quantification of costs and revenues refer to the year 2013 and were gathered from the company's accounting.

As regards the product's selling prices, which vary according to seasonal conditions and the amount of foreign potatoes entering Sicilian markets, calculations produced an average value of 48 euro/q, which was averaged between the minimum (30 euro) and maximum (65 euro) prices of early potatoes sold at major wholesale fruit and vegetable markets in Sicily in the year 2013.

\section{RESULTS}

As can be discerned from Table 3, the total cost of production is $8,345.03$ euro/ha while the per-unit cost is 46.88 euro/q. Variable costs represent the category having the greatest impact, comprising $82.5 \%$ of the total cost of production. 
Table 3. Economic results

\begin{tabular}{lrrr}
\hline Items & euro/ha & euro/q & $(\%)$ \\
\hline Cultural practices & 677.13 & 3.80 & 8.1 \\
Fertilization & 477.12 & 2.68 & 5.7 \\
Sowing & $1,004.20$ & 5.64 & 12.0 \\
Irrigation & 339.16 & 1.91 & 4.1 \\
Pesticidetreatments & 478.57 & 2.69 & 5.7 \\
Harvesting and packaging & $2,314.09$ & 13.00 & 27.7 \\
Transport & 178.00 & 1.00 & 2.1 \\
Mediation & 854.40 & 4.80 & 10.2 \\
Repair and maintanance & 345.67 & 1.94 & 4.1 \\
Interest on currentcosts & 217.82 & 1.22 & 2.6 \\
Variablecosts (A) & $6,886.16$ & 38.69 & 82.5 \\
Quotas on durablecapitals & 300.00 & 1.69 & 3.6 \\
Intellectual work & 427.20 & 2.40 & 5.1 \\
Taxes & 281.67 & 1.58 & 3.4 \\
Interests on land use & 450.00 & 2.53 & 5.4 \\
FixedCosts (B) & $1,458.87$ & 8.20 & 17.5 \\
Total Costs (C = A+B) & $8,345.03$ & 46.88 & 100.0 \\
Gross Production Value (D) & $8,544.00$ & 48.00 & \\
Profit (D-C) & 198.97 & 1.12 & \\
\hline Source our processng of &
\end{tabular}

Source: our processing of directly collected data

Of the latter costs, the principal was that spent for harvesting, that alone absorbed $27.7 \%$ of average total cost of production.

Profits amounted to 198,97 euro/ha, while profits in euro/q equaled $1,12 € / \mathrm{q}$. These results show a modest profitability of the crop.

In particular, if prices drop below 46,88 euro/q, profit is equal to zero. Taking into account the swings that sales price can undergo during the harvesting phase, as well as the variability of yields, a sensitivity analysis was performed to analyze how the economic results of the enterprise would vary with shifting sales prices and yields (Tudisca et al., 2014d).

In particular, with regard to production, average per-unit yields of 150 and $200 \mathrm{q} / \mathrm{ha}$ were considered, while selling price values of 35 and 65 euro/q were assumed.

The simulation determined profit swings between a loss of -2,208.93 euro/ha (with a yield of $150 \mathrm{q} / \mathrm{ha}$ and a selling price of 35 euro/q) and a profit of $3,678.55$ euro/ha (200 q/ha and selling price of 65 euro/q). Moreover, as is clearly inferable from Fig. 1 and 2, the break-even point in the two different yield hypotheses (150 and $200 \mathrm{q} / \mathrm{ha}$ ) equals 52.33 and 43.36 euro/q, respectively. In sum, from the results of the accounting analysis for the crop, it is noteworthy that only sales prices in excess of 46.88 euro/q manage to remunerate the factors of production.

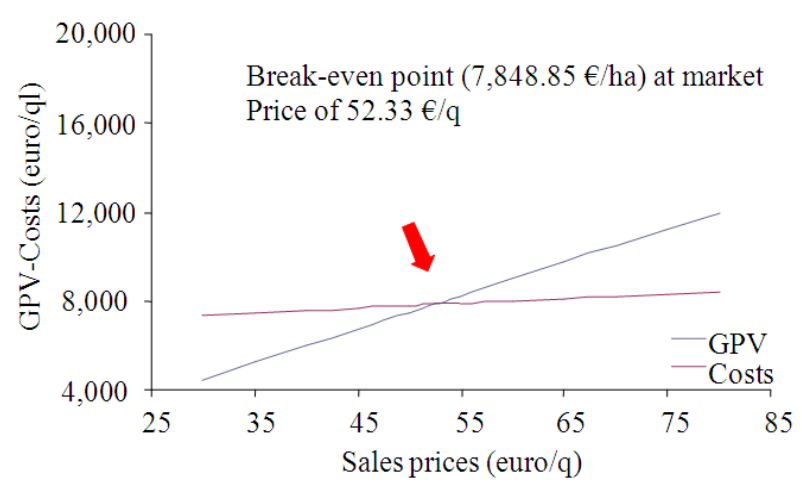

Fig. 1. Sensitivity analysis-yield 150 q/ha Source: Our processing of directly collected data

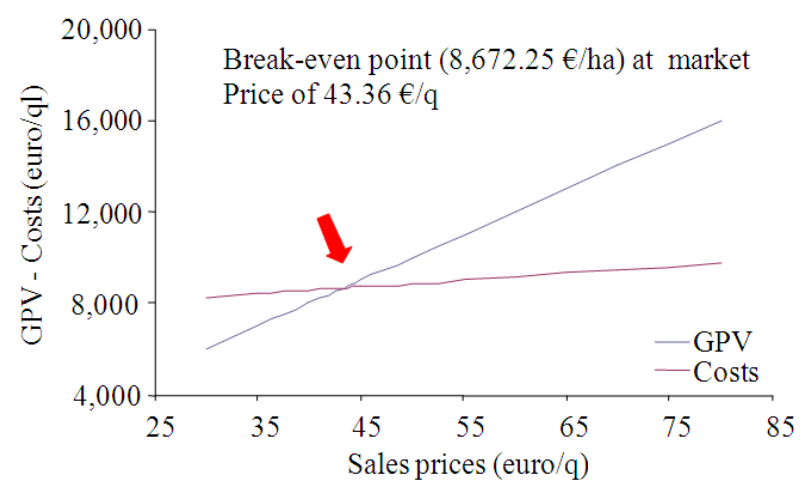

Fig. 2. Sensitivity analysis-yield 200 q/ha Source: Our processing of directly collected data

\section{DISCUSSION}

The high value of total production cost is due to the fact that many farming operations during a crop year require large amounts of human inputs. Among these, harvest (exclusively carried out manually) represent the principal cost item, as it did in other studies (Tudisca et al., 2011). The modest profitability of the crop is due essentially to the lower early potato sales price for the lack of a commercial and productive organization (Timpanaro, 2003).

This means that a slight decrease in early potato yield or in sales prices, will give farmers negative profits. In fact, farmers sold their product essentially to local wholesalers obtaining a low contractual power during price negotiations (Mora et al., 2013; Szabó and Popovics, 2009).

This situation derives from a lack of business strategies, fragmented production and offer, a shortcomings of policies aiming to enhance products, 
that lead to stagnation of agricultural activities, which lowered incomes and employment opportunities in the territorial areas of reference (Testa et al., 2014b).

So, the economic sustainability of the crop can be achieved by adopting strategies of both horizontal and vertical integration that allow an increase of early potato sales prices (Chinnici et al., 2014; Lanfranchi and Giannetto, 2013; Messori, 2005; Collins and Montgomery, 1997).

The vertical integration strategies, in fact, allow to reduce production costs and increase the farmer's income, by shortening the supply chain. The horizontal integration ones, instead, aggregate the productive supply, reaching a greater market power (George et al., 2008).

\section{CONCLUSION}

This study on early potato cultivation in the Mediterranean has highlighted a low profitability of the crop. This situation is determined by the forceful antagonistic competitive pressure exerted by the countries of North Africa, whose production costs are less. Another factor that negatively affects the competitiveness of companies is the lack of effective and efficient business formulas to follow the evolution of trends in food consumption. The higher average age of entrepreneurs also has an undesirable influence on the crop's profitability. The economic sustainability of the crop can be achieved provided business choices are reoriented, by adopting strategies of both horizontal and vertical integration. In the light of its economic track record, the future of the early potato cultivation lies in measures tending to optimize planning of product supply and favour innovative business formulas that enable enterprises to gain new impetus, allowing them to compete on the Italian market as well as on those abroad, in an attempt to cope with the increasing competition from Mediterranean countries (above all, Israel, Spain and Egypt). Economic sustainability is the prerequisite for survival of any production process over time and, therefore, of any economic activity able to create opportunities for both employment and income. In the territorial contexts, where agricultural activities represent the main economic activity, new business strategies represent the way forward. However, this strategy could also represent a new opportunity for territorial competitiveness in those contexts where agricultural activities are marginal, because it could create the conditions for investment in order to promote the attraction of capital and investment in the territory.

\section{ACKNOWLEDGEMENT}

This study is a result of the full collaboration of all the authors. However, F. Sgroi elaborated paragraph 2, A.M. Di Trapani wrote paragraph 5, R. Testa wrote paragraph 3 and 4, while S. Tudisca elaborated paragraph 1.

\section{REFERENCES}

Agnese, C., F. D’Asaro, G. Grillone and A. Drago, 2008. Comparison of temperature data collected in urban and agricultural areas surrounding. Italian J. Agrometeorol., 13: 48-49.

Cantore, V., F. Wassar, S.S. Yamaç, M.H. Sellami and R. Albrizio et al., 2014. Yield and water use efficiency of early potato grown under different irrigation regimes. Int. J. Plant Product., 8: 409-428.

Chinnici, G., G. Pappalardo and B. Pecorino, 2014. Economic evaluation of innovative solutions for food safety in cereal sector in Sicily. Quality-Access Success, 15: 41-47.

Collins, D.J. and C.A. Montgomery, 1997. Corporate Strategy: Resources and the Scope of the Firm. 1st Edn., Irwin, Chicago, ISBN-10: 0256178941, pp: 764.

D’Asaro, F., G. Grillone and R.H. Hawkins, 2014. Curve number: Empirical evaluation and comparison with curve number handbook tables in Sicily. J. Hydrol. Eng., DOI: 10.1061/(ASCE)HE.1943-5584.0000997

D'Asaro, F. and G. Grillone, 2012. Empirical investigation of curve number method parameters in the Medi-terranean area. J. Hydrol. Eng., 17: 11411152. DOI: 10.1061/(ASCE)HE.19435584.0000570

George, A.P., R.J. Nissen and R.H. Broadley, 2008. Improving horticultural supply chains in Asia and the developing economies requires a shift in strategic thinking. Acta Horticultaraea, 794: 147-154.

Grillone, G., G. Baiamonte and F. D'Asaro, 2014. Empirical determination of the average annual runoff coefficient in the Mediterranean area. Am. J. Applied Sci., 11: 89-95. DOI: 10.3844/ajassp.2014.89.95

Grillone, G., C. Agnese and F. D'Asaro, 2012. Estimation of daily solar radiation from measured air temperature extremes in the mid-mediterranean area. J. Irrigat. Drainage Eng., 138: 939-947. DOI: 10.1061/(ASCE)IR.1943-4774.0000480

Grillone, G., C. Agnese and F. D'Asaro, 2009. Estimation of solar radiation in Sicily by daily data maximum and minimum temperature. Italian $\mathbf{J}$. Agrometeorol., 14: 84-85. 
Ierna, A. and B. Parisi, 2014. Crop growth and tuber yield of "early" potato crop under organic and conventional. Scientia Horticulturae, 165: 260-265. DOI: 10.1016/j.scienta.2013.11.032

ISTAT, 2012. 6th General Agricultural Census.

Lanfranchi, M. and C. Giannetto, 2013. Analysis of the economic evaluation of an italian farm in response to the economicfinancial crisis that the EU is going through. Q. Access Success, 14: 119-124.

Messori, F., 2005. L'azienda Agraria. 1st Edn., CLUEB, Bologna, Italy, ISBN-10: 88-491-2490-2

Mora, M., M. Cortés, C. Sanhueza and C. Sáenz, 2013. Innovation requirements for the development of cactus pear for export: A new item to be incorporated to the chilean fruit export sector. Acta Horticulturae, 995: 229-236.

Prestamburgo, M. and V. Saccomandi, 1995. Economia Agraria. Etaslibri, Milano, Italy.

Rykbost, K.A., S.R. James, A.R. Mosley, B.A. Charlton and D.C. Hane et al., 2003. Modoc: A potato variety with bright red skin and early maturity for fresh market. Am. J. Potato Res., 80: 235-240. DOI: 10.1007/BF02855359

Santeramo, F.G., J. Di Pasquale, F. Contò, S. Tudisca and F. Sgroi, 2012. Analyzing risk management in mediterranean countries: The syrian perspective. New Medit, 11: 35-40.

Sgroi, F., A.M. Di Trapani, R. Testa and S. Tudisca, 2014a. Strategy to increase the farm competitiveness. Am. J. Agric. Biological Sci., 9: 394-400. DOI: 10.3844/ajabssp.2014.394.400

Sgroi, F., A.M. Di Trapani, R. Testa and S. Tudisca, 2014b. The rural tourism as development opportunity or farms: The case of direct sales in sicily. Am. J. Agric. Biological Sci., 9: 407-419. DOI: 10.3844/ajabssp.2014.407.419

Sgroi, F., S. Tudisca, A.M. Di Trapani, R. Testa and R. Squatrito, 2014c. Efficacy and efficiency of italian energy policy: The case of PV systems in greenhouse farms. Energies, 7: 3985-4001. DOI: 10.3390/en7063985

Szabó, G.G. and P. Popovics, 2009. Possible ways of market coordination and integration in the Hungarian dairy sector. J. Rural Cooperat., 37: 32-51.

Testa, R., A.M. Di Trapani, M. Foderà, F. Sgroi and S. Tudisca, 2014a. Economic evaluation of introduction of poplar as biomass crop in Italy. Renewable Sustainable Energy Rev., 38: 775-780. DOI: 10.1016/j.rser.2014.07.054
Testa, R., A.M. Di Trapani, F. Sgroi and S. Tudisca, 2014b. Economic analysis of process innovations in the management of olive farms. Am. J. Applied Sci., 11 : 1486-1491. DOI:10.3844/ajassp.2014.1486.1491

Timpanaro, G., 2003. Economic aspects and problems of the organic early potato production and market in Italy. Acta Horticulturae, 608: 109-116.

Tudisca, S., A.M. Di Trapani, E. Donia, F. Sgroi and R. Testa, 2014a. Entrepreneurial strategies of Etna wine farms. Int. J. Entrepreneurship Small Bus., 21: 155-164. DOI: 10.1504/IJESB.2014.059470

Tudisca, S., A.M. Di Trapani, F. Sgroi, R. Testa and G. Giamporcaro, 2014b. Role of alternative food networks in Sicilian farms. Int. J. Entrepreneurship Small Bus., 22: 50-63. DOI: 10.1504/IJESB.2014.062130

Tudisca, S., A.M. Di Trapani, F. Sgroi and R. Testa, 2014c. Economic evaluation of PDO introduction in Sicilian orange farms. Q. Access Success, 14: 99103.

Tudisca, S., A.M. Di Trapani, F. Sgroi and R. Testa, 2014d. Organic farming and economic sustainability: The case of Sicilian durum wheat. Q. Access Success, 15: 93-96.

Tudisca, S., A.M. Di Trapani, F. Sgroi, R. Testa and R. Squatrito, 2013a. Economic analysis of PV systems on buildings in Sicilian farms. Renewable Sustainable Energy Rev., 28: 691-701. DOI: 10.1016/j.rser.2013.08.035

Tudisca, S., A.M. Di Trapani, F. Sgroi and R. Testa, 2013b. Marketing strategies for mediterranean wineries competitiveness: The case of Pantelleria. Q. Access Success, 14: 101-106.

Tudisca, S., A.M. Di Trapani, F. Sgroi and R. Testa, 2013c. The cost advantage of Sicilian wine farms. Am. J. Applied Sci., 10: 1529-1536. DOI: 10.3844/ajassp.2013.1529.1536

Tudisca, S., F. Sgroi and R. Testa, 2011. Competitiveness and sustainability of extreme viticulture in Pantelleria Island. New Medit, 10: 57-64.

Van Der Waals, J.E., L. Korsten and F.D.N. Denner, 2003. Early blight in South Africa: Knowledge, attitudes and control practices of potato growers. Potato Res., 46: 27-37. DOI: 10.1007/BF02736100 